\title{
O INSÓLITO NA OBRA DE JOÃO GILBERTO NOLL OU O APRENDIZADO DA TRANSGRESSÃO
}

\author{
Shirley de Souza Gomes Carreira ${ }^{1}$
}

\begin{abstract}
Resumo: Na literatura brasileira contemporânea, há autores que incorporam aos seus textos acontecimentos insólitos que devem ser observados à luz das teorias relativas ao insólito ficcional. Este trabalho tem por objetivo analisar o insólito na obra de João Gilberto Noll, de modo a comprovar que a sua presença nos textos do autor constitui uma via para transgressões que operam não apenas no âmbito da diegese, mas também na arquitetura do texto.

Palavras-Chave: Insólito, João Gilberto Noll, Transgressão.
\end{abstract}

Abstract: In contemporary Brazilian literature, some authors incorporate to their texts unusual events to be observed in the light of theories concerning the fictional uncanny. This work aims to analyze the unusual in the work of João Gilberto Noll, in order to prove that its presence in the texts the author is a way for transgressions that operate not only within the diegesis, but also in the architecture of the text.

Keywords: Unusual, João Gilberto Noll, Transgression.

\section{INTRODUÇÃO}

A presença do insólito na ficção exige uma reflexão sobre a sua natureza e modos de manifestação. $O$ insólito, passado aqui da categoria de adjetivo para a de substantivo, nada mais é do que uma ruptura em relação ao sólito, isto é, ao que é habitual e previsível. No âmbito da ficção ele adquire novos contornos e geralmente irrompe como uma "crítica da ficção diante de um mundo transfigurado" (SILVA, 2013, p. 21).

Para Nicholas Royle, o insólito é "uma crise do que é próprio e natural", mas também "um encontro secreto com o que estava oculto e veio à luz" (ROYLE, 2003, p. 2).

As teorias sobre a presença do insólito na literatura apontam para a sua compreensão como elemento de categorias tais como o fantástico, o estranho e o maravilhoso, dentre outras.

${ }^{1}$ Professora Titular do ABEU - Centro Universitário, UNIABEU, Curso de Letras, Nilópolis, Rio de Janeiro, Brasil; Doutora em Literatura Comparada pelA UFRJ; membro do Grupo de Pesquisa "Poéticas do contemporâneo: estudos de sociedade, história e literatura". Endereço eletrônico: shirleysgcarr@gmail.com. 
Segundo Todorov, o gênero maravilhoso constitui o sobrenatural aceito:

[...] os elementos sobrenaturais não provocam qualquer reação particular nem nas personagens, nem no leitor implícito. Não é uma atitude para com os acontecimentos narrados que caracteriza o maravilhoso, mas a própria natureza desses acontecimentos (TODOROV, 1975, p. 60).

O gênero estranho caracteriza-se como o sobrenatural explicado, isto é, refere-se a acontecimentos que podem perfeitamente ser explicados pelas leis da razão, mas que, de uma maneira ou de outra, são incríveis, extraordinários, chocantes, singulares, inquietantes, insólitos e que, por esta razão, provocam na personagem e no leitor reação semelhante àquela produzida pelos textos fantásticos (TODOROV, 1975, p. 53).

Cabe ao fantástico a característica de se localizar no limite dos dois outros gêneros, ocorrendo em circunstâncias permeadas de incertezas. 0 fantástico é a hesitação experimentada por um ser que só conhece as leis naturais, face um acontecimento aparentemente sobrenatural (TODOROV, 1975, p. 31) e exige uma integração do leitor no mundo das personagens, uma vez que se define pela percepção ambígua que o próprio leitor tem dos acontecimentos narrados (TODOROV, 1975, p. 37).

A hesitação, a ambiguidade suscitada pelo fantástico só é possível mediante a existência desse leitor, que não é o leitor empírico, mas um leitor implícito que detém as características de um leitor potencial, idealizado, materializando um conjunto de orientações que há de guiar o possível leitor empírico no sentido de uma interpretação adequada da obra, segundo a ótica de seu autor.

Em Seis passeios pelos bosques da recepção (1994), Umberto Eco afirma que a obra literária exige um equilíbrio entre a infinidade de interpretações que pode gerar e uma hermenêutica normativa, em que os papéis do autor e do receptor são fundamentais. Há assim uma intentio operis, interpretada como uma estratégia semiótica, decorrente da leitura. A interpretação feita pelo receptor está implícita no próprio texto, uma vez que a - intenção do texto e a de produzir um leitor - modelo capaz de fazer conjeturas sobre ele (CARREIRA, 2009, p.4).

No caso específico da literatura produzida nas Américas no século XX - que tem em Gabriel García Márquez, Jorge Luís Borges e Alejo Carpentier alguns dos seus expoentes - houve uma reescritura dos padrões hegemônicos das metrópoles do Velho Mundo, que se caracterizou como discurso 
contra-hegemônico. O realismo maravilhoso, como veio a ser conhecido, desfaz a oposição entre o real e o irreal, fazendo com que os acontecimentos insólitos sejam incorporados com naturalidade no plano diegético (GARCÍA, 2013, p. 48). Há, assim, a coexistência, não excludente e harmoniosa, entre os realia e os mirabilia.

Este preâmbulo se faz necessário para que se possa analisar a presença do insólito na obra de João Gilberto Noll, uma vez que, em seus textos, os acontecimentos insólitos exigem do leitor um pacto de verossimiIhança, ou seja, uma "suspensão da descrença", conforme a concepção de Coleridge, no texto Biographia literária, em que ele explica que, na composição dos seus poemas em Lyrical Ballads, ele assumira a responsabilidade de transformar o sobrenatural em algo crível.

Na obra de Noll, o insólito assume feições particularizadas, posto que está sempre associado ao corpo, aos seus limites e ao seu potencial como instrumento de transgressão.

\section{O CORPO E A NARRATIVA COMO LÓCUS DO INSÓLITO}

Os espaços da contemporaneidade se apresentam configurados por uma perene imprecisão afetiva e identitária, consequência da fluidez que Bauman descreve em Modernidade líquida (2001). Assim, as identidades são mutáveis, não se atendo a formas ou temporalidade, assumindo um caráter móvel e inconstante (HALL, 1991, p. 13). E é precisamente essa fluidez e mobilidade que se torna perceptível na obra de Noll.

Escritor gaúcho, festejado pela crítica e detentor de vários prêmios literários, desde a estreia, Noll tem, a cada livro, surpreendido os leitores, com a sua inusitada técnica narrativa e abordagem temática. Sua narrativa cambiante, em primeira pessoa, desenrola-se em um tempo que é sempre o da leitura, uma vez que rompe com todos os paradigmas de escrita.

Em A céu aberto, é possível perceber que o insólito é a via para a desconstrução de binarismos que por muito tempo sustentaram o pensamento ocidental: real e imaginário, tempo e espaço, homem e mulher, passado e presente, dentro e fora. No universo ficcional de Noll tudo se perde nos fluxos narrativos, que compõem uma espécie de desejo em estado de escritura bruta. Incessantemente, o romance trabalha a sensação do choque e do espanto (CARREIRA, 2000, p. 42).

A narrativa começa com a iniciativa de um garoto abandonado de levar o irmão doente ao front de batalha em busca da ajuda de seu pai gene- 
ral. A princípio, seu objetivo é pedir dinheiro para comprar remédios, mas logo ele se vê alistado no exército, sem saber quem é o verdadeiro inimigo. A partir daí o leitor é levado a acompanhar o protagonista-narrador através de todo um percurso de vida, no qual o real e a fantasia se misturam, onde o passado e o presente se confundem. A guerra indefinida em um país não identificado forma o contexto onde o protagonista/narrador não nomeado se insere.

As personagens de Noll não possuem traços físicos ou psicológicos convencionais e a sua permeabilidade, na maioria das vezes, inviabiliza a existência de um nome próprio. A anomia surge, assim, como uma marca do caráter mutável das personagens, que são seres solitários e vivem suas experiências a meio caminho entre a fantasia - ou o sonho - e a realidade.

Assim, a arquitetura insólita do texto constitui uma transgressão da narrativa tradicional, que atinge seu ápice à medida que o narrador percebe em si os sinais de outras categorias de transgressão, dentre elas a que encontra no corpo o seu lócus de realização. O corpo é o lugar de onde o sujeito ensaia um grito contra tudo o que a sociedade constrói sob a forma de discurso de repressão. No espaço do corpo, os espaços geográficos se diluem, assim como o tempo, tomando novas dimensões.

Como em outros textos de Noll, em A céu aberto, o corpo surge como lócus primordial, de onde tudo eclode como ação e narrativa; as experiências sexuais, na maioria das vezes homossexuais, estão associadas à capacidade de mutação, ao trânsito entre o sexos. O insólito surge assim, como uma transgressão de qualquer posição estável, seja ela espacial, temporal ou de gênero.

Em meio à superexposição de fatos e delírios, o narrador surge indefinido quanto à própria sexualidade: "Eu, que pensara já estar cansado de ser macho, de estar ali presente com o pau duro misturado às demandas de outro corpo..." (NOLL, 1996, p.127).

As personagens de Noll rejeitam qualquer tipo de encarceramento social e só são capazes de conhecer a si mesmas por meio da transgressão dos códigos que as sufocam e igualam. Em $A$ céu aberto, as personagens ocupam múltiplas posições de sujeito, e os corpos transcendem as categorias socialmente impostas. Assim, o irmão, único ponto de ancoragem do narrador, transforma-se em mulher:

Quando voltei o meu irmão estava diante do fogão aguardando a subida do leite que fervia. Ele vestia uma camisola azulada que lhe vinha até os pés 
descalços. Transparente a camisola, e do outro lado do tecido fino havia o corpo de uma mulher. Precisarei romper com esse negocio de pensar nessa figura aí como meu irmão, falei dentro de mim. Cheguei perto e vi que o leite vinha subindo. Virei o botão do fogão, o leite estancou. Perguntei cheirandoIhe o pescoço levemente perfumado se ela andava distraída. Ela suspirou e fingiu que voltava a si. Eu já era um homem apaixonado, ainda mais por saber que aquele corpo percorrera um itinerário tão tortuoso para chegar até ali. Dentro daquele corpo de mulher deveria existir a lembrança do que ele fora como homem, e boliná-lo como eu fazia naquele instante deixava em mim a agradável sensação de estar tentando seduzir a minha própria casa, onde eu encontraria o meu irmão quem sabe em outro momento. Não, o meu irmão não morrera naquele corpo de mulher, ele permanecia lá dentro esperando a sua vez de voltar, e eu beijava um pedaço de seio à mostra e desamarrei a camisola e disse que queria um filho dela e disse que não queria um filho dela, pois que estava bom assim sem filho sem nada, para que uma criança entre nós dois se uma outra poderá ressurgir daí na pele do meu irmão? (NOLL, 1996, p. 76-77).

Esses corpos que submergem e emergem continuamente, que se misturam e se transformam, constituem algo que causa estranhamento ao leitor. Se por um lado o leitor empírico pode atribuir às sensações do narrador o efeito de uma alucinação ou delírio, conferindo ao insólito o estatuto do estranho descrito por Todorov, por outro, o próprio protagonista se coloca hesitante ante os acontecimentos que descreve, desenhando os contornos da definição do fantástico.

Esse eu que se materializa em outros "eus", que se desdobra e desfaz continuamente, é o reflexo do homem da sobremodernidade, descrito por Augé (1994): um sujeito errante, transeunte perpétuo dos não lugares, que tem nas sensações corpóreas, vivenciadas até a última gota, não apenas um meio de transgressão, mas também de transcendência.

A mulher que o narrador pressente nos corpos masculinos surge de modo a desestabilizar qualquer noção de identidade fixa: "Mais um corpo a me trazer a lembrança do meu irmão... Mais um corpo que parece masculino e que em meio ao exército, em meio à guerra é revirado pela mão de algum deus que lhe puxa lá de dentro a mulher até então enterrada?" (NOLL, 1996, p. 139).

No romance é significativa a passagem em que o narrador se coloca diante do espelho e percebe que, do outro lado, não há mais ninguém além dele, que, à sua volta, todas as formas parecem se desmanchar. Após essa constatação, ele sai em busca do irmão, "para garantir uma vida fora do espelho" (NOLL, 1996, p. 66). 
Em Sobre os espelhos, Eco (1989, p. 22) reflete sobre a associação entre o nome próprio e a imagem especular como elementos identificadores, atribuindo à imagem o estatuto de "nome próprio absoluto", por sua relação direta com o referente. A imagem que o narrador vê o faz transitoriamente feliz, mas a fuga e a busca do outro sugere a rejeição do eu coerente, em prol de uma multiplicidade de "eus", de uma vida sem códigos, mutável.

Assim como os referentes espaço-temporais são nebulosos, a identidade tem contornos imprecisos.

Em Lorde, o protagonista também se depara com acontecimentos insólitos. O enredo do romance é aparentemente simples: um indivíduo não nomeado, o narrador, do qual sabemos apenas que é de nacionalidade brasileira, viaja à Inglaterra a convite de um representante de uma universidade britânica para exercer a função de writer in residence. Lá chegando, ele se vê imerso em dúvidas não apenas sobre o seu real motivo para estar ali, como também sobre as verdadeiras intenções daquele que o convidou. O romance é tecido a partir dos meandros das incertezas do narradorprotagonista, cuja deambulação pela cidade equivale a um mergulho em busca do seu verdadeiro eu. De concreto, ele sabe apenas que não viera para Londres para dar conferências nem para representar país algum: viera para ser um outro que nem mesmo ele sabia como deveria ser.

Em uma dessas andanças, encontra George, com quem se relaciona sexualmente. $O$ relacionamento tem o estatuto de um ritual de passagem. Ao acordar, o narrador busca pelo companheiro, ouve o chuveiro, vê o vapor que vem do banheiro. Observa que o ruído do chuveiro cessa, como se o banho tivesse terminado, mas lá dentro do banheiro, como constata a seguir, não há ninguém. Imagina-se ilhado, prisioneiro outra vez, só que de uma cidade inexistente. Sua angústia é tanta que decide romper o trato que fizera consigo mesmo: olha-se no espelho, embaçado pelo vapor e pelo resto de sêmen que ainda traz nas mãos. A imagem que vê o assusta:

A primeira coisa que vi foi o sol rodeado de raios tatuado no meu braço. Abaixei a cabeça para não surpreender o resto. Murmurei: Mas era no meu braço esse sol ou no deeorge? O espelho confirmava, não adiantava adiar as coisas com indagações. Tudo já fora respondido. Eu não era quem eu pensava. Em consequência, George não tinha fugido, estava aqui. Pois é, no espelho apenas um: ele (NOLL, 2009, p. 109).

Subitamente, sua ambição tornara-se realidade: era outro homem. Como a convencer-se de que ainda estava ali, dentro daquele corpo, o nar- 
rador repete para o espelho que é professor de língua portuguesa. Imagina que talvez possa sonhar o sonho do outro, apropriar-se da matriz de sua alma. Ciente da metamorfose, ele começa a indagar-se sobre a possibilidade de uma identidade sobrepujar a outra. Sua identidade acabara de ser traduzida em outro corpo: o do homem tatuado que encontrara em um pub e que fora seu companheiro por uma noite. No entanto, ainda é ele quem articula a visão do outro. O orgasmo assume literalmente a feição de uma "pequena morte", em que dois seres deixam de ser quem são passando a ser uma terceira criatura.

A metamorfose, recorrente na obra de Noll, está também presente em Acenos e afagos. No romance, o protagonista, significativamente denominado João Imaculado, casado e pai de um adolescente, sente-se oprimido pelo desejo que nutre por um amigo, agora engenheiro, com quem, na infância, teve um encontro homoerótico.

Em um ansiado reencontro, o amigo assume a sua homossexualidade e o narrador antevê a oportunidade de concretizar seus desejos, o que, no entanto, não acontece, pois o amigo parte em uma viagem. Em busca de uma satisfação alternativa, o narrador se entrega a toda sorte de relacionamentos, até que um garoto de programa o agride e o mata. Miraculosamente, é graças ao amigo, regressado e inexplicavelmente presente no cemitério em que o narrador é enterrado, que ele ressuscita; fato este que a ele mesmo causa estranheza: "Ainda existia alguma margem para milagres?" (NOLL, 2008, p. 89).

Tão fantástica quanto a sua ressurreição é a sua súbita estada no interior de Mato Grosso, onde, no papel de mulher do engenheiro, observa seu corpo masculino transformar-se aos poucos em um corpo feminino.

Ironicamente, cabe a ele o papel ativo nas relações sexuais com o engenheiro:

Mas quem era eu afinal? Um homem que funcionaria como esposa dentro de casa. Um cara fodão à noite, varando o engenheiro até o seu caroço. [...] 0 engenheiro tinha uma mulher que à noite lhe introduziria um cacete doído de bom. Pois essa mulher era eu. Precisava me acostumar com a situação. [...] $\mathrm{E}$ isso que eu me considerava um homem razoavelmente viril. Meu registro de baixo. Alguma malhação. Músculos para o gasto, pelo na perna. Quem manda eu me apaixonar por esse homem desde sempre (NOLL, 2008, p. 95).

O insólito é a via para questionamentos próprios do nosso século, ou seja, se a identidade está vinculada ao gênero: "[...] ali, eu às vezes era mais mulher que muitas outras. De repente poderia acordar me sentido mais 
homem que nunca [...]. Temia que minha vida pudesse desandar. la me constituindo em uma mulher o conteúdo de um homem" (NOLL, 2008, p. $100,108)$.

A hesitação, do leitor e da própria personagem, ante a sua nova e insólita condição refletem, conforme afirma Jimenez (2010), o questionamento de uma masculinidade que não seja estritamente heterossexual, uma vez que o narrador não se sente apto a assumir nenhum dos papéis sociais convencionais:

[...] me perguntava se queria de fato me converter ao outro sexo [...]. Mas não me sentia ainda preparada para ser fêmea de vez [...] Acudiu-me a ideia de que essa privação serviria de merecimento para a minha alforria da condição feminina, ou mesmo da masculina. Não haveria uma terceira condição? [...]. Já podia passar como mulher em qualquer triagem de gênero (NOLL, 2008, p. 110, 155, 187).

Em A máquina der ser, o insólito também está associado ao corpo como território da busca do encontro com o outro, em um mundo redimensionado pela compressão espaço-temporal, permeado pelo absurdo inerente à condição humana. $O$ absurdo se apresenta como uma relação entre o homem e o mundo, nasce do confronto entre ambos (CAMUS apud RIBEIRO, 1996, p. 173). Assim, na garganta de um cadáver, palavras que jamais serão ditas coagulam; em uma queda fatal, um homem sente suas últimas ideias se tornarem pastosas e escorrerem definitivamente para fora de sua cabeça e uma mulher vive seu dia com tal intensidade que chega a escorrer sangue de seu corpo na hora de dormir.

Em "Monges", aparece a figura do duplo, tão cara à literatura gótica. Em uma de suas idas quase diárias ao shopping, o narrador, um escritor que escreve um romance e relê livros da infância, vê refletido na vitrine o misterioso rosto de um homem. Essa visão o perturba a ponto de ele ter receio de virar o rosto e encarar o homem. Temendo o confronto, ele busca distanciar-se do outro. Depois de algum tempo na praça de alimentação, o narrador vai ao banheiro do cinema e, ao abrir a porta de uma das privadas, dá de cara com o homem do reflexo. Nesse ínterim, ocorre uma batida policial no banheiro e o narrador é solicitado a mostrar seu RG para o policial, que passa o número para uma central de controle e libera o narrador. 0 policial dirige-se então para a privada onde estava o homem do reflexo. 0 narrador sai do banheiro e ouve o barulho de um tiro.

Ao leitor resta conjeturar sobre a natureza do duplo. A semelhança física é um dado que não pode ser descartado, uma vez que leva o policial a 
solicitar ao narrador a cédula de identidade. No entanto, há leituras subjacentes possíveis e uma delas aponta para um tema recorrente na obra de Noll, a dissolução da identidade. A estandardização cultural do homem contemporâneo tira-lhe toda a oportunidade de individualização, o outro é sempre um reflexo do eu.

$\mathrm{Na}$ introdução ao livro $O$ insólito e seu duplo (GARCÍA \& MOTTA, 2009 , p. 8), Júlio França nos faz lembrar que "os desdobramentos das imagens do eu, as autoduplicações da consciência, podem revelar tanto a semelhança quanto a diferença. Contudo a aversão ao "outro", produzida pelo duplo antagônico, possui uma força ainda mais terrível [...] mantém com o sujeito uma estranha familiaridade".

Conforme afirma Pereira,

A identidade do indivíduo, porém, não se restringe àquela que está registrada no documento de identidade. A identidade é um fenômeno muito mais abrangente, que extrapola nome, filiação, data e local de nascimento. Diante da insuficiência desses dados para a montagem de um projeto de identidade, o indivíduo tende a buscar no seu próprio corpo - o dado que dele está mais próximo- a fonte de sua identidade. Acontece que nem mesmo a pretensa unicidade do corpo é garantia de identidade (PEREIRA, 2008, p. 4).

Assim, os protagonistas de Noll apresentam uma relação ambígua com o outro, de atração e repulsa, que se manifesta também no âmbito do próprio corpo, que sofre metamorfoses, torna-se andrógino, se desintegra e se recompõe.

Segundo Noll, os contos de A máquina de ser falam de sujeitos em posição limítrofe, que lhes poderá representar o fim ou um novo ciclo, "alguém vivendo um instantâneo tardio e ao mesmo tempo inaugural, mesmo sabendo que não disporá mais de tempo para desfrutar dessa epifania já sustentada por varizes" (NOLL apud TRIGO, 2006).

Os contos de $A$ máquina de ser ecoam o funcionamento da máquina de relatos de $A$ cidade ausente, de Ricardo Piglia, pois evocam a existência de uma máquina de poiesis. Só tem forma aquilo que é recriado pela linguagem. O contradiscurso se concretiza na palavra, engenhosamente tecido por Noll por via do insólito.

\section{O INSÓLITO E O CONTRADISCURSO}

A utilização do insólito como meio para a manifestação dos contradiscursos não é algo novo. O Estranho Caso de Dr. Jekyll e Mr. Hyde, roman- 
ce de Robert Louis Stevenson, publicado em 1886, já apresentava a imagem do duplo como um modo de reflexão sobre a dualidade da natureza humana.

Em $O$ retrato de Dorian Gray, um retrato pintado por Basil Hallward se enfeia e degenera em compasso perfeito com a consecução dos atos sombrios praticados pelo jovem Dorian Gray, que lhe servira de modelo. Obcecado pela própria beleza e pela eterna juventude, o jovem não hesita em praticar atos abomináveis que acrescentam à pintura traços de enveIhecimento. Quando Dorian mata Basil, o quadro torna-se monstruoso, assustando-o ao ponto de desejar recuperar a própria alma. No entanto, isso só se torna possível com a destruição do quadro e a consequente morte de Dorian.

Ao projetar na imagem pintada as fraquezas de caráter de Dorian, Oscar Wilde desvela ante o olhar do leitor do século XIX aquilo que a falsa moralidade da época buscava esconder. $\mathrm{O}$ insólito torna-se, assim, a via para o contradiscurso.

A metamorfose é o recurso utilizado por Virgínia Woolf em Orlando, citado aqui para possibilitar uma fuga ao exemplo máximo do fantástico, que é a Metamorfose, de Kafka.

Orlando é um jovem inglês do século XVI que, durante uma viagem, simplesmente acorda mulher. A personagem é dotada de imortalidade e o livro acompanha Orlando por seus 350 anos de vida. O romance expõe as ambiguidades da identidade feminina e masculina e suas relações com a condição humana.

Assim, é possível verificar que as estratégias utilizadas por Noll em suas narrativas são reelaborações de outros discursos ficcionais, porém revestidas de sua visão pessoal e das inquietações do mundo contemporâneo.

\subsection{A natureza insólita da narrativa como contradiscurso}

Em A céu aberto, a ruptura da estrutura tradicional da narrativa constitui por si só um elemento do contradiscurso. Não obstante a presença de acontecimentos insólitos no âmbito da diegese, o autor apela para a indefinição dos referentes usuais da narrativa, como tempo e espaço.

A imprecisão geográfica dos locais onde a ação se desenrola - espaços urbanos, paisagens rurais e o oceano - corrobora a indefinição identitária do protagonista. 
A maior parte das referências espaciais se reporta aos locais de passagem. Os poucos locais nomeados apresentam um nome fictício, que não encontra correspondência no mundo geográfico do leitor. Portanto, a trajetória do narrador não se apoia na verossimilhança espacial; ao contrário, deixa, ao longo do texto, uma interrogação: seria essa uma trajetória vivida ou imaginada?

No romance, todos os dados que contribuem para a constituição da memória são dissimulados ou omitidos, no intuito de quebrar a noção de temporalidade. O esvaziamento da memória, decorrente de uma espaçotemporalidade movediça, colabora para intensificar a crise identitária do narrador: "Não sei mais me concentrar [...] dou demais de mim a cada chamado de fora, sofro um sério estado de evasão e custo a perceber um outro eventual encargo de atenção. Tudo me confunde já: custo a unir o que veio antes o que aconteceu depois" (NOLL, 1996, p. 81).

A ausência de contextualização é evidenciada na fala do próprio narrador, que, no entanto, pela via do discurso, acaba por situar-se no mundo contemporâneo ao mencionar guerras historicamente localizáveis: "[...] e eu aqui agora de farda, caçado para a condição de soldado numa guerra a que nem sabia que nome dar. Ora todas as guerras têm nome ou alguma coisa assim que clareie o entendimento: Vietnã, Coreia, Paraguai..." (NOLL, 1996, p. 66)

\section{A GUISA DE CONCLUSÃO}

A escrita de Noll é transgressora, conforme procuramos evidenciar ao longo do texto, e a transgressão que promove ocorre em dois níveis distintos, no âmbito do universo ficcional e na arquitetura do texto. Em ambos os casos, o autor faz uso do insólito, da sensação de estranheza em relação a paradigmas estabelecidos.

Em relação à narrativa, a quebra dos referentes espaço-temporais e a anomia concede ao leitor não apenas a possibilidade de abordar o texto com o seu conhecimento de mundo, imprimindo-lhe - ou não - um sentido que se concretizará no momento da leitura, mas também, e de uma forma quase sempre pautada no estranhamento, conforme afirma o próprio autor em entrevista concedida a Ronaldo Bressane, a oportunidade de levantar a "pele da linguagem" e refletir sobre a complexidade da existência. 
A escrita de Noll não é de fácil assimilação; reveste-se de elementos que tanto prendem quanto afastam o leitor: uma linguagem prosaica, a constante presença de acontecimentos insólitos, a obsessão pela decadência, pelo esvaziamento do ser, pelo homoerotismo, pelas relações socialmente proibidas, pelo choque.

Cabe ao leitor aceitar ou não a proposta de viagem, porque a literatura de Noll é errante, como assim são as personagens por ele criadas. 0 trânsito permanente, as mutações físicas e emocionais não são apenas sofridas pelos seres de papel. O leitor dificilmente sairá incólume do ato da leitura.

\section{REFERÊNCIAS}

BAUMAN, Zigmunt. Modernidade liquída. Trad. Plínio Dentzien. Rio de Janeiro: Zahar, 2001.

BUTLER, Judith. Gender Trouble: Feminism and the Subversion of Identity. London: Routledge, 1990.

BRESSANE, Ronaldo. Em busca da obra em aberto. [Entrevista]. Revista A. 2000. Disponível em: <http://www.joaogilbertonoll.com.br/entrevista_revis ta_a.htm>. Acesso em: 12 out. 2004.

CARREIRA, Shirley S. G. A céu aberto: a poética da transgressão. Lucero, Berkeley, University of California, v. 11, p. 42-51, 2000.

CARREIRA, Shirley S. G. A identidade traduzida em Lorde, de João Gilberto Noll. Revista Eletrônica do Instituto de Humanidades, Duque de Caxias, UNIGRANRIO, v. 5, n. 20, p. 72-88, jan.-mar. 2007. Acesso em: 22 dez. 2013.

CARREIRA, Shirley S. G. As relações entre o insólito e os leitores empírico e virtual. Revista Eletrônica do Instituto de Humanidades. Duque de Caxias, UNIGRANRIO, v. 8, n. 31, p. 13-29, out./dez. 2009. Disponível em: $<$ http://publicacoes.unigranrio.edu.br/index.php/reihm/article/viewFile/895 /578>. Acesso em: 21 set. 2010.

ECO, Umberto. Obra aberta. 8. ed. São Paulo: Perspectiva, 1991.

ECO, Umberto. Lector in fabula. A cooperação interpretativa nos textos narrativos, trad. de Attílio Cancian. São Paulo: Perspectiva, 1986.

ECO, Umberto. Sobre os espelhos e outros ensaios. Trad. Beatriz Borges. Rio de Janeiro: Nova Fronteira, 1989.

ECO, Umberto. The role of the reader: explorations in the semiotics of texts: Explorations in the Semiotics of Texts. Bloomington: Indiana University Press, 1979.

ECO, Umberto. Interpretação e superinterpretação. São Paulo: Martins Fontes, 1997. 
ECO, Umberto. Os Limites da interpretação. Lisboa: Difel, 1992.

ECO, Umberto. Seis passeios pelos bosques da recepção. São Paulo, Cia das Letras, 1994.

GARCÍA, Flavio. Discursos fantásticos de Mia Couto- mergulhos em narrativas curtas e de média extensão em que se manifesta o insólito ficcional. Rio de Janeiro: Dialogarts, 2013.

GARCÍA, Flavio; MOTTA, Marcus Alexandre. O insólito e seu duplo. Rio de Janeiro: UERJ, 2009.

HALL, Stuart. A identidade cultural na pós-modernidade. Trad. Tomaz Tadeu da Silva. Rio de Janeiro: DP\&A, 1991.

NOLL, João Gilberto. Acenos e afagos. Rio de Janeiro: Record, 2008.

NOLL, João Gilberto. A céu aberto. São Paulo: Companhia das Letras, 1996.

NOLL, João Gilberto. A máquina de ser. Rio de Janeiro: Nova Fronteira, 2006.

NOLL, João Gilberto. Lorde.

JIMENEZ, Michele de Oliveira; MACHADO E SILVA, Regina Coeli. Sexualidade e identidades conflitantes em Acenos e Afagos, de João Gilberto Noll, Terra roxa e outras terras, v. 18 (out. 2010), p. 26-37. Disponível em: http://www.uel.br/pos/letras/terraroxa. Acesso em: 8 jan. 2014.

ROYLE, Nicholas. The uncanny. Manchester: Manchester University Press, 2003.

SILVA, Luciana Morais da. Novas insólitas veredas: leitura de a varanda do frangipani, de Mia Couto, pelas sendas do fantástico. Rio de Janeiro: Dialogarts, 2013.

TODOROV, Tzvetan. Introdução à literatura fantástica. São Paulo: Perspectiva,1975.

TRIGO, Luciano. João Gilberto Noll: "Na minha literatura acesso insólitas figurações carnais". Revista Continente online, 1 nov. 2006. Disponível em: http://www.revistacontinente.com.br/index.php/component/content/article /2349.html. Acesso em: 8 jan. 2014.

WOOLF, Virginia. Orlando: A Biography. London: Penguin Books, 1993 [1928]. 



\section{RESENHA}

\section{MURILO RUBIÃO — 20 ANOS DEPOIS DE SUA MORTE}

Referência da obra resenhada:

BATALHA, Cristina; GARCÍA, Flávio. (Org.). Murilo Rubião - 20 anos depois de sua morte. Rio de Janeiro: EdUERJ, 2013.

Mariana Silva Franzim ${ }^{1}$

Adelaide Caramuru Cezar ${ }^{2}$

O livro Murilo Rubião - 20 anos depois de sua morte é composto por sete ensaios e foi organizado porMaria Cristina Batalha e Flavio García, professores da UERJ. É resultante de evento ocorrido na Universidade Estadual do Rio de Janeiro entre 16 e 18 de novembro de 2011. Além dos sete ensaios, faz-se presenteno volume conto inédito do autor homenageado, "As unhas", publicado por Vera Lúcia Andrade e Ana Cristina Pimenta da Costa Val, em novembro de 1994 no Suplemento Literário de Minas Gerais. A divulgação do referido conto é acrescida de leitura crítico-interpretativa do mesmo efetivada por Prof. Dr. Flavio García. Trata-se do artigo de abertura da obra aqui resenhada:"Aspectos dos discursos fantásticos contemporâneos, pegados 'às unhas', em um conto 'não pronto para a publicação'.

O suporte teórico do qual o crítico se serviu para efetivação da leitura do conto rubiano foi artigo de Renato Prada Ortopeza, semioticista, professor, crítico literário, ficcionista e roteirista de cinema boliviano, publicado em 2006: El discurso fantástico contemporâneo: tensión semântica y efecto estético. $O$ trabalho de Prada Ortopezaatém-se a três contos de autores hispano-americanos contemporâneos de Murilo Rubião: "La cena", de Al-

1 Mestranda no Programa de Pós-Graduação em Letras/Estudos Literários junto à Universidade Estadual de Lonfrina (UEL), Londrina, Paraná. Endereço eletrônico: marianafran zim@gmail.com.

2 Professor Associado C da Universidade Estadual de Lonfrina (UEL), Londrina, Paraná; doutorado em Letras pela Universidade Estadual Paulista Júlio de Mesquita Filho; integrante do GT da ANPOLL "Vertentes do insólito ficcional". Endereço eletrônico: accezar @uel.br. 